Article

\title{
REFLECTIONS ON THE STRUGGLE AGAINST THE FREE TRADE AGREEMENT (FTA), THREE DECADES ON
}

\section{WILLIAM K. CARROLL UNIVERSITY OF VICTORIA}

The editors have posed excellent questions on what was at stake in the 1980s-1990s struggles against 'free trade', and what the relevancies of those struggles are for the left today. My contribution responds to each question, in sequence.

How did you become involved in the struggles around free trade in the 1980s?

In the consolidation of transnational neoliberalism, 'free trade' between Canada and the US marked a significant moment. For Canadian nationalists (whether conservatives inspired by George Grant's [1965] Lament for a Nation or leftists following in Kari Levitt's [1970] dependentista footsteps), the central issue was sovereignty. The worry was that Canada's distinctive traditions, its national aspirations for well-rounded development, and even the capacity of Canadians to govern themselves, would be sacrificed on the soulless altar of market transactions under the thumb of an imperial power. For many liberals, and also some centrist social democrats such as my colleague at the University of Victoria, Terrance Morley (Palmer 2007), closer economic ties between the neighbouring countries would be mutually beneficial, supporting economies of scale, higher incomes and a tax base for improved social programs. Lurking beneath the surface of 'free trade', however, was the deeper reality of class power. Yet this reality was tightly entangled with the politics of nation. As Jorge Niosi observed in 1983, 'the most important cleavage among Canadian socialists is the one between Nationalists and Internationalists' (1983:128). I will return to this issue later in this article.

I have placed 'free trade' in inverted commas because, like other items in the neoliberal lexicon, it obscures much more than it reveals. By the time a comprehensive agreement between Canada and the US was officially mooted in the 'leap of faith' recommended by Donald Macdonald, Chair of the Royal Commission on the Economic Union and Development Prospects for Canada, my own research and activism had led me, with colleagues, to a critique of 'restraint' (more inverted commas), which was the buzzword coined by BC's Social Credit government to frame Canada's first full-fledged neoliberal program, launched in 1983. I had moved to Victoria two years earlier as a newly-minted York $\mathrm{PhD}$, and soon became active in the popular resistance to 'restraint' - participating both in the broad Solidarity Coalition (Carroll 1984) and, on campus, 
in the Committee on Alternatives for British Columbia, which I co-founded with four UVic colleagues late in 1983.

My involvement in the struggle against 'free trade' was constrained by a sabbatical leave (1987-88) and then by intensive parenting after our first son was born in 1989, followed by \#2 son in 1992. That first sabbatical took me to Amsterdam for a year, where I joined up with the Amsterdam School of Gramscian international political economy and focused on setting Canada within the transnational spread of neoliberalism (Carroll 2019). Upon my return, our Committee on Alternatives organized a forum featuring John Warnock's newly-published Free Trade and the New Right Agenda. Warnock's book set out clearly what was at stake. He recognized the class issue at the centre of the 1988 'free trade' agreement, as the deal would serve as a 'new "Business Charter of Rights"' for transnational corporations on both sides of the border (1988:22). ${ }^{1}$

I was interested in how 'free trade' fit within the wider hegemonic project of neoliberalism, which I have understood, with David Harvey and other Marxist political economists, as, indeed, a class project. In a paper I presented in 1989, published in 1990, I offered a Gramscian take on Canada's multi-tiered transition, beginning in the late 1970s, from the fordist-Keynesian politics of class compromise to what I called 'continental neoliberalism'. This combined Jorge Niosi's (1983) claim that the Canadian bourgeoisie, having come of age, now advocated 'continental nationalism' to secure access to the vast US market, with Leo Panitch's (1987) observation that USCanada 'free trade' would smuggle the Reagan revolution into Canada, by the back door. I wrote: The strategic unity of continentalism and neoliberalism lies in the mechanism that the emerging common market provides for shifting the balance of class forces in Canada to the advantage of capital. As capital circuits become more fully continental, investment will flow to the cheapest and most compliant sections of the North American workforce. The organizationally decimated American working class will set the standards in Canada (407).

In this way, 'free trade' was the linchpin in a passive revolution, to enhance capitalist class power, in Canada and ultimately across the continent. Indeed, with Mexico brought into the economic zone via NAFTA, this logic became accentuated, to the detriment of North American workers, and Mexican peasants - many of whom were dispossessed with Mexico's turn to industrial agriculture for export northward.

Given the already low tariffs that had been engineered under the General Agreement on Tariffs and Trade (GATT) over the post-World War Two decades, 'free trade' was primarily about investor rights and, for Canadian capitalists, securing undisturbed access to the US market as a right-wing populist, elected in 1980 on the slogan 'make America great again', threatened protectionism (Weinberg 2019). Yet among many on the left in Canada, what was at stake was framed in nationalist terms, as the defence of Canada in the face of American imperialism.

\footnotetext{
${ }^{1}$ At the same time, and spinning off from our Committee on Alternatives, a group of us at UVic launched an interdisciplinary critical theory graduate program. This initiative claimed much of my time in 1988-1989. Warren Magnusson, professor of Political Science, provided crucial leadership in both the Committee on Alternatives for BC and the interdisciplinary program in Cultural, Social and Political Thought.
} 
In his study of the Macdonald Commission, Gregory Inwood (2005:9-10) noted that the contending sides in the 'free trade' debate were divided between neoconservative continentalism (pro) and nationalist social democracy (anti), with the latter emphasizing an interventionist role for the state, up to and including industrial policy, and a sharp critique of foreign control (ibid: 106), generally unaccompanied by concerns about capitalist control per se. A nationalist defense of the Keynesian welfare state was at the centre of the rhetoric developed by the Council of Canadians (formed in 1986 shortly after the release of the Macdonald Commission's report) and the Pro-Canada Network (formed in 1987, at the Council of Canadians Maple Leaf Summit, which ran alongside the Mulroney-Reagan 'Shamrock Summit' where the Free Trade Agreement was further solidified [Bleyer 1997:138]).

Defensive mobilization is the characteristic form that popular movements take, since subalterns rarely have the resources needed to advance radical, system-transforming claims (Tilly 1978). For socialists the challenge is always to move beyond defense, and 'beyond the fragments' of single-issue politics (Rowbotham et al 2013). In the circumstances, 'free trade' offered the advantage of being a single issue 'unlike any other': 'a distillation of a broader socioeconomic agenda' - that of neoliberalism (Bleyer 1997:141). The nationalist social-democratic framing of 'free trade' provided another immediate advantage. It affirmed the value of the Canadian status quo, and thus resonated strongly with the existing identities and aspirations of many Canadians. Grounded theoretically in the dependency school of Canadian political economy, this framing could also claim a distinctively Canadian intellectual pedigree, reaching back to the staples thesis of Harold Innis (1930), as further elaborated by Mel Watkins (1963), Daniel Drache (1977) and others.

As Nancy Fraser (1995) has argued, remedies to socio-political maladies can take an affirmative or transformative form. In calling for continuity, the nationalist social-democratic alternative to continental neoliberalism exemplified the former. Fraser went on to point out a certain paradox, familiar to left intellectuals and activists alike. Affirmative remedies, such as defense of the Keynesian Welfare State (Fraser's own example), gain traction relatively easily, since they for the most part affirm existing identities. In the 1980s, such a defensive posture comprised the low-hanging fruit of mainstream social democracy as it grappled with emergent neoliberalism. Yet Fraser went on to argue that affirmative responses engage only with surface-level adjustments, which leave the underlying 'generative mechanisms' of injustice intact. On the other hand, transformative remedies (here, her leading example was socialist projects) have the potential for systemic change, but they have difficulty gaining popular traction, since they take us out of our comfort zones, materially and discursively, while often stirring powerful opposition from above. They press against the hegemonies that most people have taken on as common sense. Given this reward structure, there is a strong tendency in popular movements toward affirmative framings, guiding defensive rather than offensive mobilization.

Part of my own interventions around this issue was a sympathetic critique of the nationalist social-democratic frame, which tended to deflect attention from the centrality of class to issues 
that could be packaged within a mildly reformist program. The affirmative frame gained traction in the critique of American domination, but it failed to educate workers and activists about neoliberal globalization, and capitalist domination. It failed to name what we were actually struggling against. In placing national sovereignty at the centre of the narrative, it veiled the class relations - the generative mechanisms - that actually drove 'free trade', and thereby failed to articulate the need for an alternative to capitalist class power. ${ }^{2}$

The three-way 'free trade' agreement known as NAFTA, brought into effect half a decade after CUFTA, in turn served as the template for other investor-rights agreements - confirming that US-Canada 'free trade' was not an expression of an exceptional bilateral relationship of Canadian dependence, but simply one (major) step in a hegemonic project of transnational neoliberalism, requiring an internationalist and class-based response from the left. The project proceeded at different scales, the subnational (as in BC's 'restraint' program of 1983), the national, and the transnational (as GATT was transfigured into WTO, in 1995). Key to that project have been deregulation of capital, including the international flow of goods and capital (backed up by investor rights), attacks on state debt and deficits combined with lowered taxes especially on capital and high-income earners (requiring in turn a curtailment of the public sector and social wage), privatization and other forms of accumulation by dispossession, and abrogation of trade union rights.

To what extent were these struggles successful?

The struggles in Canada against 'free trade' were, in an immediate sense, entirely unsuccessful, as CUFTA and NAFTA, enacted according to plan, provided the model for investor rights agreements elsewhere, and thereby helping to consolidate neoliberalism transnationally. A measure of that consolidation as it played out in Canada, is that by 2019, three decades on from CUFTA, there was no visible, organized opposition to Canada's continuing participation in the North American economic zone. In the lead-up to the 'new NAFTA', which largely reproduces the same template, there were no voices from the popular sector challenging NAFTA itself. Public opinion in Canada was generally supportive of the revised framework reached in $2019,{ }^{3}$ as was the Council of Canadians, whose efforts contributed to several reforms to the arrangement (Dey 2019).

\footnotetext{
${ }^{2}$ Yet in the mobilization against 'free trade' there were also activist currents that viewed the situation more accurately, in terms of its class politics. Common Frontiers - a continental coalition of unions and other left organizations, still active today - stands out. Established during the debates around the Canada-US Free Trade Agreement (CUFTA), Common Frontiers continues to provide 'a forum for groups to discuss issues, strategize and coordinate campaigns,' grounded in 'recognition that cooperation must extended across sectors nationally and also across borders.' https://www.commonfrontiers.ca/about-us/

${ }^{3}$ An ABACUS poll conducted in December 2019 found that 77\% of Canadians (and 85\% of NDP supporters) consider the 'new NAFTA' 'a good thing for Canada'. https://abacusdata.ca/nafta-cusma-polling-canada-abacus-data/
} 
As we have seen, Canada was not exceptional along the road to neoliberal hegemony; the 'paradigm shift' (McBride 2001) has been general across the capitalist democracies of the core. But if with CUFTA/NAFTA the participating states gained ignominious distinction in creating the prototype for transnational investor rights agreements, this was not the first time that Canadian state practices inspired innovations for ruling classes elsewhere. We might recall how Canada's reserve system, a program to exterminate Indigenous people by attrition, furnished the architects of South African Apartheid with a working model, embellished by direct consultation with Canadian state officials, for their own racial-capitalist project (Bourgeault 1988; Bélanger with Yoon 2018). Both Apartheid and 'free trade' teach us that, within the global capitalist order, the contested terrain that is the Canadian state has stayed decidedly on the side of colonialism and imperialism - a lesson relayed clearly in recent studies of Canadian imperialism (Gordon 2010b; Klassen 2014; Kellogg 2015). As Gordon (2010a) has observed,

Canadian foreign and military policy developments over the past 20 years have been shaped by the rapid growth of Canadian capital's presence in the Global South and the ensuing conflicts with local communities and anti-neo-liberal governments. Canada's ruling elites have a clear stake in ensuring that the Third World remains a safe place to do business. Their aim is to ensure - to use the language of Foreign Affairs and International Trade (DFAIT) and the Canadian International Development Agency (CIDA) - "stability" "predictability" and "transparency" for Canadian investors. Not surprisingly, imposing liberalized market relations (which constitute "stability" "predictability" and "transparency") and exploiting the South have become a central goal of Canadian foreign policy, as evidenced in policy documents coming out of DFAIT and CIDA. This in turn entails a more aggressive attitude towards any country or organization deemed to be threatening Canada's financial interests or the sanctity of liberalized free markets more generally.

By implication, assessment of the broader legacy of the struggle against 'free trade' requires an international purview.

What is the legacy of the struggle against free trade today? What lessons can be learned?

NAFTA came into force on January 1, 1994. On that day, in southern Mexico, the Zapatistas began an uprising that would capture the imagination of an incipient global left, while placing Indigenous claims on the agenda of opposition to transnational neoliberalism. Indeed, the years following NAFTA's enactment saw pitched struggles, by the neoliberal globalizers to advance their agenda and by popular movements to oppose that advance. In the crucible of struggle, the opposition's self-understanding shifted from affirming settled identities to something more interesting, for socialists. In a process of 'social movement learning' that is intrinsic to activism (Hall et al 2011), opposition to neoliberal globalization became framed not as the defense of national sovereignty, but as a proactive pursuit of global justice and democratization. 
The trajectory of the Council of Canadians illustrates this shift, as did the rebranding of the ProCanada Network as Action Canada Network after the 1988 election, with an expanded agenda for social justice that included sponsorship of Common Frontiers (Bleyer 1997:141-3). By December 1999, Canadian activists, many of them members of the Council of Canadians, found themselves in Seattle, shoulder-to-shoulder with US-based activists, holding their own against militarized police and managing to shut down the inaugural ministerial meeting of the World Trade Organization. Indeed, in struggles against the Multilateral Agreement on Investment in 1998, the WTO in 1999 and the Free Trade Area of the Americas in 2001, the Council of Canadians reinvented itself. By 1999, the Council's guide for activists rejected 'the old ideas of "nationalism" and "national sovereignty." The Council proposed 'popular sovereignty' as a common basis of action, reflecting 'the dreams and aspirations of people who live in a political community (like a neighbourhood, city, province or country) and who remain connected with peoples around the world in the struggle for social and economic justice' (quoted in Carroll 2003: 52). An important aspect of this escape from the nationalist box was the shift 'from a focus on American corporations to corporate hegemony broadly defined, and from a preoccupation with trade to other issues..., notably the privatization of the "global commons" (Coburn 2011: 218). The successes of international campaigns ${ }^{4}$ inspired activists in Brazil to establish the World Social Forum in 2001, which sought common ground in the global struggle against neoliberal capitalism.

Space does not allow an account of what transpired in the ensuing years - which brought further developments on the global left, particularly the rise of 'pink tide' governments in Latin America, but concurrently the 'new imperialism' of stepped-up accumulation by dispossession (including protracted war in west Asia) and, interleafed with the latter, the consolidation of neoliberal globalization.

The last two questions are key, looking ahead.

To what extent is the struggle against free trade still a problem? How has it changed?

We still need to view 'free trade' as part of a larger hegemonic project, and 'free trade' agreements as frameworks for shifting class power and enlarging investor rights in various ways extending to intellectual property rights and financial services. Critiquing that project, and forwarding a coherent alternative that moves beyond defensive, affirmative politics are key priorities in my view.

As for what has changed, for many in the Global North, across several decades the ideological dominance of neoliberalism brought 'free trade' into the vocabulary of common sense. Yet, three decades on, neoliberal globalization and its discontents, including the degeneration of social democracy into neoliberalism-lite, has opened space for alternatives to neoliberalism. Until quite recently, the main beneficiaries have been on the right. Indeed, the affirmative politics of identity have been playing out rather differently from the 'free trade' debates of the 1980s and

${ }^{4}$ MAI and FTAA were both scrapped; the WTO Ministerial was aborted. 
1990s. The new nationalism is explicitly right-wing. This is not difficult to understand, since nationalist discourse is not based in any principled sense of social justice, but comprises a basic form of identity politics, typically affirming status-quo identities and the social relations underwriting them. And in the epicentre of right-wing nationalism, bankrolled by far-right billionaires (Nesbit 2016), the Tea Party and kindred groups filled that new political space offering up, in 2016, a billionaire presidential candidate who ironically built his brand in opposition to 'free trade' (but not investor rights). Of course, there has also been, relatedly, the renewal of the left in the US, which is a hopeful sign. Mass action, led as I write this by Black Lives Matter, reveals deep contradictions baked into the US version of racial capitalism.

Three decades under CUFTA also marks three decades from James Hansen's 1988 warning to the US Senate of the causal link between carbon emissions and global warming. As with 'free trade', the climate emergency needs to be set within a radical political economy/ecology sensitized to capital and class, and global in perspective. Research on the development of a transnational capitalist class, in which Canada's bourgeoisie is well ensconced (Carroll 2004; Klassen and Carroll 2011), has highlighted the class agency behind transnational neoliberalism (Robinson and Harris 2000; Carroll 2010), which extends to the project of 'Climate Capitalism' (Sapinski 2016) - whether at the World Economic Forum, the World Business Council for Sustainable Development, the COP meetings (where Big Oil has held pride of place, Corporate Europe Observatory 2019) or in the efforts of Bill Gates and Canadian fossil-fuel billionaire Murray Edwards to create a profitable basis for geoengineering (Vidal 2018).

Colleagues and I at in the Corporate Mapping Project, a community-university partnership I have co-led since 2015, have charted the economic, political and cultural relations and practices that comprise a 'regime of obstruction' in Canada, protecting the revenue streams of fossil capital under the cover of a national interest in maintaining Canada's status as an 'energy superpower' (Carroll 2020). Canada now ranks third globally in upstream carbon emissions (somewhat behind the US and slightly behind second-ranked Saudi Arabia) and first in the world in CO2 emission intensity per barrel of oil equivalent produced, owing to the extreme carbon-intensity of bitumen extraction, which typically emits 'three to five times more CO2 per barrel than the global average' (Rystad Energy 2020).

The extraction of carbon from the earth is a well-entrenched industry in Canada, but not any more than in the US, which in recent years became a major exporter of oil, and which has always, like Canada, relied on its substantial natural-resource endowment as a prime motor of capital accumulation within a settler-colonial project.

In the past decade or so, the emergence in the South, from Indigenous struggles, of an analysis of extractivism (Acosta 2013; Rivera Andía and Vindal Ødegaard 2019; Dunlap and Jakobsen 2020), has offered conceptual resources more nuanced than the staples/dependency analysis of the 1960s and 1970s that helped frame the struggle against 'free trade'. ${ }^{5}$ As a critical

\footnotetext{
${ }^{5}$ The key critiques of the concept of staples are by McNally (1981) and Kellogg (2015). Some proponents of the staples thesis have recently grafted it onto an extractivist analysis. See for instance the collection edited by Bélanger (2018).
} 
concept, extractivism calls attention to the damage done to living systems, and to the humans whose own lives are immersed in them, by capital's practices of accumulation. It weaves together an ecological critique with a critique of colonialism, two issues that had only marginal salience in the left-nationalist thinking and campaigns of the 1970s and 1980s. ${ }^{6}$ The problem of extractivism runs far deeper than the 'hewers of wood and drawers of water' metaphor that Innis popularized in Canada in the 1930s (Bowles and MacPhail 2018), which posits secondary manufacturing as a curative for resource extraction. Extractivism is grounded not in Canadian exceptionalism but in the logic of capital within the web of life (Moore 2015), creating and reproducing a metabolic rift on an extended scale, in pursuit of endless growth within a finite ecosystem (Foster 2000), and often dispossessing Indigenous peoples of their lands as an integral part of the process. The issue is just as fundamental in, say China or the US - leading centres of extractivist capitalism, with enormous carbon footprints - as in Canada.

The other sea change, intersecting with the critique of extractivism and the deepening climate crisis, has been Indigenous resurgence, sparked in Canada most visibly in 2012 by Idle No More (Coulthard 2014; Simpson 2017). If US-Canada 'free trade' was misunderstood by leftnationalists as a colonizing project - the final chapter in 'silent surrender' - throughout the neoliberal era the real process of colonization within Canada proceeded apace, as it became refitted to the larger logic of corporate globalization. The clearest expression of this came from Stephen Harper's mentor, Tom Flanagan, whose 2010 book, Beyond the Indian Act, called for the liberation of 'dead capital' on reserves, eliminating the collective land ownership that has insulated Indigenous communities from full incorporation into capital's circuitry (Gutstein 2014: 106-36). Although the proposal was not enacted, a targeted strategy of coopting Indigenous leadership via partnership arrangements with fossil-fuel companies and other corporate players has proliferated, concurrently with Indigenous resurgence (Pasternak and King 2019:10-11). The dilemma between bourgeois modernization and collective resurgence has recently expressed itself in a conflict between band leadership as mandated by the Indian Act and hereditary leadership - the contention around construction of the BC Coastal Gaslink pipeline across Wet'suwet'en land being a prime example (Brown and Bracken 2020). In contrast to the vision of Indigenous autonomy within collective ways of life, the bourgeois-modernist version of self-determination envisages Indigenous peoples as sovereign participants in capitalism, capturing a monetized stream of benefits from resource extraction, within 'a despiritualized world understood simply as a business opportunity' (Coburn and Atleo 2016: 190).

In short, 'free trade' is one of several interrelated developments that have shaped the current crisis-ridden conjuncture. The complex, cumulative impact of transnational neoliberalism now includes its normalization as established policy and common sense, its partial unraveling since the financial crisis of 2008, and the ensuing far-right nationalist reaction. And, alongside other

\footnotetext{
${ }^{6}$ An important exception is Mel Watkins's (1977) edited collection of briefs made to the Berger Inquiry, documenting the (successful) efforts of the Dene people to prevent construction of the Mackenzie Valley pipeline, which would have traversed their land.
} 
political-ecological elements - the deepening climate crisis, the growing critique of extractivism, Indigenous resurgence - the covid-19 pandemic must also be taken into account. This publichealth emergency has exposed fundamental problems in neoliberal globalization. Indeed, less than three decades after neoliberal champion Francis Fukuyama declared the 'end of history', ${ }^{7}$ Alfredo Saad-Filho (2020) has, in view of the pandemic, declared 'the end of neoliberalism.' Recalling similar pronouncements in the financial meltdown of 2008, Saad-Filho's declaration overstates the case, yet the intersecting crises have certainly rendered transnational neoliberalism highly vulnerable to critique, and to alternatives.

How do you think people on the left can effectively confront the project of free trade today while at the same time challenging both far-right nationalism and neoliberal globalization?

Far right nationalism is a reactionary response to capitalism's deepening crisis, which neoliberal globalization has accelerated. These two hegemonic projects are quite distinct in how they privilege dominant-class interests. Neoliberalism constructs hegemony from a money-capital standpoint, emphasizing the sanctity of deregulated markets in a tendentially borderless world, the immediate interests of mobile, internationalized capital and the supposed benefits to all from higher productivity and lower prices in a global marketplace (Jessop and Overbeek 2019). Far-right nationalism constructs hegemony from a productive capital standpoint (as did European fascism in the 1930s, Van der Pijl 1984). In recruiting popular consent, the emphasis is on trickle-down of jobs and wages from accumulation within a national economy restored to its former 'greatness'. The difference is personified in the contrast between Justin Trudeau, a leading progressive neoliberal, and Donald Trump.

As I have emphasized, 'free trade', whether the TPP, CETA or CUSMA, is a pillar of neoliberal globalization. In my view, we are well past the point where left-nationalism in Canada makes much sense, though along with other nationalisms, it retains capacity to mobilize in an affirmative way, in defense of a Canadian 'national interest' (also a term that requires inverted commas). Yet, as Gramsci famously noted, 'the international situation should be considered in its national aspect ... the line of development is toward internationalism but the point of departure is "national"' (1971:240). The challenge for the left is to reposition national-popular tropes, disentangling them from the hegemonic discourses of the capitalist state, setting them within an alternative whose trajectory is toward internationalism: the common interest we share in creating a world in which human thriving and ecological health are regnant values. ${ }^{8}$

\footnotetext{
${ }^{7}$ Fukuyama has since recanted (Eaton 2018).

8 I have explored how transnational actors like the Transnational Institute and Focus on the Global South have been building the infrastructures of dissent that can help advance these politics of justice globalism (Carroll 2016). The recent establishment of a Progressive International, recognizing that 'our politics may never be more fertile for internationalism than they are right now' is a hopeful development (Mann et al 2020).
} 
'Thriving' and 'health' are keywords here, and they point to an ideological opening catalyzed by the pandemic. As free-market capitalism and its political devotees proved incapable of a coherent response, public-health professionals became the recognized leaders, even heroes, and the concern for human welfare, generally secondary in societies governed by capital-logic and largely irrelevant to neoliberalism, became primary - thus Saad-Filho's pronouncement, quoted above. Unsurprisingly, as the first wave of the pandemic in Canada subsided in the late spring of 2020, the capitalist class and its acolytes, temporarily sidelined by their own political bankruptcy, were already calling for a return to business-as-usual (Climenhaga 2020).

Meanwhile, politicians like Justin Trudeau have assumed the mantle of ethico-political leadership in progressive, cosmopolitan neoliberalism today, which appears as the main alternative to far-right nationalism. The left needs to present an alternative that rejects both of these hegemonic projects and points toward green, democratic socialism, both locally and globally. 'Pointing toward' means making transitional demands, within a framework of what I have called robust radicalism (Carroll 2015), for system-transforming reforms that erode power-over while empowering those currently on the receiving end of domination to exercise power-with collaborating with peers in relationships of mutual support (Carroll and Sapinski 2018: 123). Such a power shift implies a shift in social logic, from the 'rational choices' of abstract individuals in the anarchic market to the substantive rationality of participatory planning (Harnecker 2015). And implicit in participatory planning is the principle of subsidiarity: that decision-making, where feasible, should be brought to the level of communities rather than centralized in distant extralocal sites - whether corporate or state.

As alternatives to neoliberal globalization, these ideas resonate with Walden Bello's (2009) notion of deglobalization: "re-embedding" the economy in society, instead of having society driven by the economy.' Yet deglobalization does not mean a return to closed-border parochialism. The climate crisis (and the pandemic) alert us also to the necessity of planning and coordination, on a global scale, to match the scale of the crisis. As Mario Candeias (2013:19) has emphasized, a green and just transition from transnational neoliberalism will require global planning of resource flows to ensure a just distribution of wealth that meets the needs of those worst affected by climate change, while limiting consumption and addressing reproductive needs -- as sectors stoking climate breakdown and resource depletion shrink while others (including the entire care economy) qualitatively expand. The collective agency for transition to 'democratic eco-socialism' (Satgar 2018) is emerging, though in Canada this political current is weak. Still, The Leap, and now the Canadian Green New Deal are significant initiatives to build a pro-active coalition similar to the Action Canada Network of the early 1990s, but bearing stronger ties to Indigenous and ecological communities and organizations. These latter movements are not propelled by Canadian nationalism; indeed, resurgent Indigenous politics problematizes what left-nationalists of the latter $20^{\text {th }}$ Century took for granted: the legitimacy of the Canadian state itself.

I believe the urgent existential crisis posed by climate breakdown can catalyze radical thinking and acting. But only if the left is able to connect the dots between climate and capitalism 
in a way that insists upon an exit from extractivism and colonialism. ${ }^{9}$ Given capitalism's global reach, these transformations must also reach beyond national borders, which requires building a green left with transnational scope. Yet a global green left must find its footing in local and national politics, constructing pathways in consciousness and action that lead beyond affirmations of national identity. In all this, the struggle against both transnational neoliberalism and far-right nationalism occupies centre stage.

\section{References}

Acosta, A. 2013 [2011]. Extractivism and Neoextractivism: Two Sides of the Same Curse. In M. Lang \& D. Mokrani (eds.), Beyond Development: Alternative Visions from Latin America (pp. 61-86). Amsterdam: Transnational Institute.

Artellea, Kyle A., Melanie Zurbac, Jonaki Bhattacharyyad, Diana E. Chane, Kelly Browne, Jess Houstyf and Faisal Mo. 2019. 'Supporting resurgent Indigenous-led governance: A nascent mechanism for just and effective conservation.' Biological Conservation 240: 1-10

Bélanger, Pierre (ed.). 2018. Extraction Empire: Undermining the Systems, States, and Scales of Canada's Global Resource Empire, 2017-1217. Boston: MIT Press

Bélanger, Pierre with Kate Yoon. 2018. 'Canada's Apartheid.' Pp. 684-93 in Pierre Bélanger (ed.), Extraction Empire: Undermining the Systems, States, and Scales of Canada's Global Resource Empire, 2017-1217. Boston: MIT Press

Bello, Walden. 2009. 'The Virtues of Deglobalisation.' Transnational Institute 3 September https://www.tni.org/es/node/11276.

Bleyer, Peter. 1997. 'Coalitions of social movements as agencies for social change: the case of the Action Canada Network.' Pp. 134-150 in William K. Carroll (ed.), Organizing Dissent. Toronto: Garamond Press.

Bourgeault, Ron. 1988. 'Canada [and its] Indians: The South African Connection.' Canadian Dimension 21(8) January: 6-10

\footnotetext{
${ }^{9}$ As Artellea et al (2019:1) show, 'resurgent Indigenous governance' offers an effective and socially just way to achieve biodiversity conservation.
} 
Bowles, Paul and Fiona MacPhail. 2018. 'Contesting natural resource development in Canada: the legacies and limits of the staples approach.' British Journal of Canadian Studies 31 (2): 167179.

Brown, Alleen and Amber Bracken. 2020. No surrender: after police defend a gas pipeline over Indigenous land rights, protestors shut down railways across Canada.' The Intercept 23 February $\quad$ https://theintercept.com/2020/02/23/wetsuweten-protest-coastal-gaslinkpipeline/

Candeias, Mario. 2013. Green Transformation: Competing Strategic Projects. Berlin: Rosa Luxemburg Foundation. http://www.rosalux-nyc.org/green-transformation/.

Carroll, William K. 1984. 'The Solidarity Coalition.' Pp. 94-114 in Warren Magnusson, William K. Carroll, Charles Doyle, Monika Langer, and R.B.J. Walker (eds.), The New Reality. Vancouver: New Star Books.

Carroll, William K. 1990. 'Restructuring capital, reorganizing consent: Gramsci, political economy, and Canada.' Canadian Review of Sociology and Anthropology 27:390-416.

Carroll, William K. 2003. 'Undoing the end of history: Canada-centred reflections on the challenge of globalization.' Pp. 33-56 in Yildiz Atasoy and William K. Carroll (eds.), Global Shaping and its Alternatives. Toronto: Garamond Press.

Carroll, William K. 2004. Corporate Power in a Globalizing World. Toronto: Oxford University Press.

Carroll, William K. 2010. The Making of a Transnational Capitalist Class. London: Zed Books. With Meindert Fennema, Colin Carson, Eelke Heemskerk and JP Sapinski as collaborators.

Carroll, William K. 2015. 'Robust radicalism.’ Review of Radical Political Economics 47:663-668.

Carroll, William K. 2016. Expose, Oppose, Propose: Alternative Policy Groups and the Struggle for Global Justice. London and Halifax: Zed Books and Fernwood Publishing.

Carroll, William K. 2019. 'Reflections on the Amsterdam School and the transnational capitalist class.' Pp. 197-201 in Bob Jessop and Henk Overbeek (eds.), Transnational Capital and Class Fractions: The Amsterdam School Perspective Reconsidered. London: Routledge. 
Carroll, William K. 2020. 'Fossil capitalism, climate capitalism, energy democracy: The struggle for hegemony in an era of climate crisis.' Socialist Studies 14(1):1-26.

Carroll, William K. and J.P. Sapinski. 2018. Organizing the 1\%: How Corporate Power Works. Halifax: Fernwood Publishing.

Climenhaga, David. 2020) 'Harper, Kenney and the usual suspects see the pandemic as an opportunity.' The Tyee 15 May https://thetyee.ca/Analysis/2020/05/15/Harper-KenneySee-Pandemic-Opportunity/

Coburn, Elaine. 2011. 'Resisting neoliberal capitalism: insights from Marxist political economy.' Pp. 194-226 in Gary Teeple and Stephen McBride (eds.) Relations of Global Power: Neoliberal Order and Disorder. Toronto: University of Toronto Press.

Coburn, Elaine and Clifford Atleo. 2016. 'Not just another social movement: Indigenous resistance and resurgence.' Pp. 176-194 in William K. Carroll and Kanchan Sakar (eds.), A World to Win. Winnipeg: ARP Books.

Corporate Europe Observatory. 2019. 'Corporate COP25: the biggest failure so far?' 12 December https://corporateeurope.org/en/2019/12/corporate-cop25-biggest-failure-sofar?utm_source=dlvr.it\&utm_medium $=$ facebook

Coulthard, Glen. 2014. Red Skin, White Masks. Mineapolis: University of Minnesota Press.

Dey, Sujata. 2019. 'NAFTA 3.0: Better, but still leaving much to be desired.' Council of Canadians. https://canadians.org/analysis/nafta-30-better-still-leaving-much-be-desired

Drache, Daniel. 1977. 'Staple-ization: a theory of Canadain capitalist development.' Pp. 15-33 in Craig Heron (ed.), Imperialism, Nationalism, and Canada. Toronto: New Hogtown Press and Between the Lines.

Dunlap A., Jakobsen J. 2020. 'Introduction: consuming everything-capitalism and the imperative of total extractivism.' In A. Dunlap and J. Jakobsen (eds.), The Violent Technologies of Extraction. Palgrave Pivot, Cham

Eaton, George. 2018. 'Francis Fukuyama interview: "Socialism ought to come back." New Statesman 
Flanagan, Tom, and Christopher Alcantara and Andre Le Ressay. 2010) Beyond the Indian Act: Restoring Aboriginal Property Rights. Montreal and Kingston: McGill-Queen's University Press.

Foster, John. 2000. Marx's Ecology. New York: Monthly Review Press.

Fraser, Nancy. 1995. 'From redistribution to recognition? Dilemmas of justice in a "post-socialist" age.' New Left Review 212:68-93.

Gordon, Todd. 2010a. 'Canada's imperialist project: capital and power in Canadian foreign policy.' Briarpatch 5 May https://briarpatchmagazine.com/articles/view/canadae28099simperialist-project-capital-and-power-in-canadian-foreign-pol

Gordon, Todd. 2010b. Imperialist Canada. Winnipeg: ARP Books.

Gramsci, Antonio. 1971. Selections from the Prison Notebooks. New York: International Publishers.

Grant, George. 1965. Lament for a Nation. Toronto: McClelland \& Stewart.

Gutstein, Donald. 2014. Harperism. Toronto: Lorimer.

Hall, Budd L., Darlene E. Clover, Jim Crowther and Eurig Scandrett. 2011. 'Social movement learning: a contemporary re-examination.' Studies in the Education of Adults 43(2):113116.

Harnecker, Marta. 2015. A World to Build. New York: Monthly Review Press.

Innis, Harold A. 1930. The Fur Trade in Canada. Toronto: University of Toronto Press.

Inwood, Gregory J. 2005. Continentalizing Canada: The Politics and Legacy of the Macdonald Royal Commission. Toronto: University of Toronto Press.

Jessop, Bob and Henk Overbeek (eds.). 2019. Transnational Capital and Class Fractions: The Amsterdam School Perspective Reconsidered. London: Routledge.

Kellogg, Paul. 2015. Escape from the Staple Trap: Canadian Political Economy after Left Nationalism. Toronto: University of Toronto Press. 
Klassen, Jerome. 2014. Joining Empire: The Political Economy of the New Canadian Foreign Policy. Toronto: University of Toronto Press.

Klassen, Jerome and William K Carroll. 2011. 'Transnational Class Formation? Globalization and the Canadian Corporate Network.' Journal of World-Systems Research 17: 379-402.

Levitt, Kari. 1970. Silent Surrender. Toronto: Macmillan of Canada.

McBride, Stephen. 2001. Paradigm Shift: Globalization and the Canadian State. Halifax: Fernwood Publishing.

Mann, Geoff, Thea Riofrancos, and David Adler. 2020. Introducing: The Inaugural Blueprint Collection. $\quad$ Progressive International $\quad 8 \quad$ May https://progressive.international/blueprint/bed8719f-4c2d-4d19-850c-3f574e4c66c9introducing-the-inaugural-blueprint-collection/en

Moore, Jason W. 2015. Capitalism in the Web of Life: Ecology and the Accumulation of Capital. London: Verso.

Nesbit, Jeff. 2016 Poison Tea: How Big Oil and Big Tobacco Invented the Tea Party and Captured the GOP. New York: Thomas Dunne Books.

Niosi, Jorge. 1983. 'The Canadian bourgeoisie: towards a synthetical approach.' Canadian Journal of Political and Social Theory 7(3):128-49.

Palmer, V. 2007. 'A prophet of the left in B.C., Terry Morley knew politics inside out' [final edition]. The Vancouver Sun Oct 12 Retrieved from http://search.proquest.com.ezproxy.library.uvic.ca/docview/242041119?accountid=14846

Panitch, Leo. 1987. 'Capitalist restructuring and labour strategies.' Studies in Political Economy 24: 131-49.

Pasternak, Shiri and Hayden King. 2019. Land Back: A Yellowhead Institute Red Paper. Toronto: Yellowhead Institute, September https://redpaper.yellowheadinstitute.org/

Van der Pijl, Kees. 1984. The Making of an Atlantic Ruling Class. London: Verso.

Rivera Andía, Juan Javier and Cecilie Vindal Ødegaard. 2019. 'Introduction: Indigenous Peoples, Extractivism, and Turbulences in South America.' Pp. 1-50 in Cecilie Vindal Ødegaard and 
Juan Javier Rivera Andía (eds), Indigenous Life Projects and Extractivism. Approaches to Social Inequality and Difference. Palgrave Macmillan, Cham, available at https://link.springer.com/chapter/10.1007/978-3-319-93435-8_ 1

Robinson, William I. and Jerry Harris. 2000. 'Towards a global ruling class? Globalization and the transnational capitalist class.' Science \& Society 64(1): 11-54.

Rowbotham, Sheila, Lynne Segal and Hilary Wainwright. 2013. Beyond the Fragments: Feminism and the Making of Socialism. Halifax: Fernwood Publishing.

Rystad Energy. 2020. 'US tops upstream oil \& gas CO2 emitters list - Canada has highest intensity, Norway lowest.' 28 May https://www.rystadenergy.com/newsevents/news/pressreleases/us-tops-upstream-oilgas-co2-emitters-list-canada-has-highest-intensity-norwaylowest/?mkt tok=eyJpIjoiTUdJM1pEZzFabVJoWVdaayIsInQiOiJtS1MrakV6bEZUV0Vx VU83SHZaaXNQQ1N5TINlZHY3bzN0Nlk5dFF1a3BkTmRBb05sNkRsWExSbHZsVVJ4 U1ZFOHFOZTVPWjNaSzZic1h5SzlVNII0S3laZkZScUo5SDJSXC9CK2NpZnNaS3VjS3p 1SEYrXC9ibUY1SnN3QkIzSmM2In0\%3D

Saad-Filho, Alfredo. 2020. 'Coronavirus, Crisis, and the End of Neoliberalism.' The Bullet April 17 https://socialistproject.ca/2020/04/coronavirus-crisis-and-the-end-of-neoliberalism/

Sapinski, JP. 2016. 'Constructing climate capitalism: corporate power and the global climate policy-planning network.' Global Networks 16: 89-111.

Satgar, Vishwas. 2018. 'The climate crisis and systemic alternatives.' Pp. 1-27 in Vishwas Satgar (ed.). 2018. The Climate Crisis. Johannesburg: WITs University Press.

Simpson, Leanne Betasamosake. 2017. As We Have Always Done: Indigenous Freedom through Radical Resistance. Minneapolis: University of Minnesota Press.

Tilly, Charles. 1978. From Mobilization to Revolution. New York: Addison-Wesley

Vidal, John. 2018. 'How Bill Gates aims to clean up the planet.' The Guardian 4 February https://www.theguardian.com/environment/2018/feb/04/carbon-emissions-negativeemissions-technologies-capture-storage-bill-gates

Warnock, John. 1988. Free Trade and the New Right Agenda. Vancouver: New Star Books. 
Watkins, Mel H. 1963. 'A staple theory of economic growth.' Canadian Journal of Economics and Political Science 29:141-58.

Watkins, Mel (ed.). 1977. Dene Nation: The Colony Within. Toronto: University of Toronto Press.

Weinberg, Abigail. 2019. 'Donald Trump did not coin the phrase "Make America great again".' Mother Jones 2 April https://www.motherjones.com/politics/2019/04/donald-trump-didnot-coin-the-phrase-make-america-great-again/ 